\title{
Claims-Based Co-management in Norway's Arctic? Examining Sami Land Governance as a Case of Treaty Federalism-ERRATUM
}

\author{
Aaron John Spitzer ${ }^{1}$ and Per Selle ${ }^{2}$ \\ ${ }^{1}$ University of Bergen and ${ }^{2}$ University of Bergen
}

In the original publication of this article, the following textual errors were mistakenly included:

On page 5, the last sentence of the second full paragraph should read, "Hence, in this article, we compare FeFo with the Indigenous co-management archetype that is ubiquitious in Canada and prominent in discussions of treaty federalism," rather than "[...] archetype, which is ubiquitous in Canada [...]" (emphasis added).

On page 6, the last sentence of the first paragraph of section 2.1 should read, "Hence, Canadian claims boards enjoy "quasi-constitutional status" (White, 2008: 72)" rather than, "[...] claims that boards enjoy [...]."

On page 8 , the last sentences of the paragraph starting on the preceding page and the third full paragraph should both end "[...] renewal and removal of "their" board members," rather than "[...] renewal and removal of their board members."

On page 12, the first sentence of the first full paragraph should read, "White reports that, especially early on in Canada, nominating governments often failed to respect the principle of independence, demanding allegiance from "their" members," rather than "[...] demanding allegiance from their members."

Cambridge University Press apologizes for these errors.

\section{Reference}

Spitzer, Aaron John and Per Selle. 2019. "Claims-Based Co-management in Norway's Arctic? Examining Sami Land Governance as a Case of Treaty Federalism." Canadian Journal of Political Science: 1-19. doi:10.1017/S0008423919000301.

Cite this article: Spitzer AJ, Selle P (2019). Claims-Based Co-management in Norway's Arctic? Examining Sami Land Governance as a Case of Treaty Federalism-ERRATUM. Canadian Journal of Political Science 52, 937-937. https://doi.org/10.1017/S0008423919000751

(C) Canadian Political Science Association (l'Association canadienne de science politique) and/et la Société québécoise de science politique 2019 